\title{
Darwin wasps (Hymenoptera: Ichneumonidae) of Mexico: subfamily Rhyssinae
}

\section{Аарвиновские наездники (Hymenoptera: Ichneumonidae) Мексики: подсемейство Rhyssinae}

\author{
A.I. Khalaim ${ }^{1,2}$, E. Ruíz-Cancino ${ }^{1}$, J.M. Coronado-Blanco ${ }^{1}$ \\ А.И. Халаим ${ }^{1,2}$, Э. Руис-Канцино ${ }^{1}$, Х.М. Коронадо-Бланко ${ }^{1}$
}

\footnotetext{
${ }^{1}$ Facultad de Ingeniería y Ciencias, Universidad Autónoma de Tamaulipas, Cd. Victoria, Mexico.

${ }^{2}$ Zoological Institute, Russian Academy of Sciences, St. Petersburg, Russia. E-mail: akhalaim@gmail.com

2 Зоологический институт Российской академии наук, Санкт-Петербург, Россия.
}

KEY WORDS: parasitoids, Epirhyssa, Megarhyssa, Nearctic region, North America, fauna, synonymy, taxonomy, key.

КЛЮЧЕВЫЕ СЛОВА: паразитоиды, Epirhyssa, Megarhyssa, Неарктика, Северная Америка, фауна, синонимия, систематика, определительный ключ.

PALABRAS CLAVE. parasitoides, Epirhyssa, Megarhyssa, Región Neártica, Norteamérica, fauna, sinonimia, taxonomía, clave.

ABSTRACT. Mexican species of the subfamily Rhyssinae are reviewed. Two genera, Epirhyssa Cresson with five species and Megarhyssa Ashmead with three species, are recorded from Mexico. Costa Rican species E. corralesi Gauld, 1991 was found to be a junior synonym of the Mexican species E. oaxaca Porter, 1978, syn.n. Epirhyssa frohbergi Gauld and E. theloides Porter are recorded from Mexico for the first time, and E. theloides is also newly recorded from Guatemala. Identification keys to genera and species of Rhyssinae occurring in Mexico are provided.

РЕЗЮМЕ. Дан обзор мексиканских видов подсемейства Rhyssinae. Отмечены из Мексики род Epirhyssa Cresson с пятью видами и род Megarhyssa Ashmead с тремя видами. Установлено, что $E$. corralesi Gauld, 1991 из Коста-Рики является младшим синонимом мексиканского вида E. oaxaca Porter, 1978, syn.n. Epirhyssa frohbergi Gauld и E. theloides Porter отмечены впервые из Мексики, а $E$. theloides также впервые указан для Гватемалы. Даны определительные ключи обитающих в Мексике родов и видов подсемейства Rhyssinae.

RESUMEN. Se revisaron las especies mexicanas de la subfamilia Rhyssinae. Se registran para México dos géneros: Epirhyssa Cresson con cinco especies y Megarhyssa Ashmead con tres. La especie E. corralesi Gauld, 1991 de Costa Rica es un sinónimo junior de E. oaxaca Porter, 1978, syn.n. Epirhyssa frohbergi
Gauld y E. theloides Porter son registradas para México por primera vez; E. theloides se registra para Guatemala. Se elaboraron claves para la determinación taxonómica de géneros y especies de los Rhyssinae de México.

\section{Introduction}

Rhyssinae is a worldwide subfamily of Darwin wasps - the name suggested for the Ichneumonidae by Klopfstein et al. [2019] — that comprises eight genera and about 260 species [Yu et al., 2016; Broad et al., 2018] and is most species-rich in the Oriental region [Kamath, Gupta, 1972]. Historically, rhyssines were treated as a tribe within the Pimplinae [Townes, Townes, 1960; Townes, 1969; Fitton, Gauld, 1976], but subsequently were raised to subfamily level [Gauld, 1991; Wahl, Gauld, 1998]. Species of the subfamily, especially the genus Megarhyssa Ashmead, 1900, are the largest and most spectacular insects among the Ichneumonidae with body length (including ovipositor) up to $150 \mathrm{~mm}$. Females possess a long and thin ovipositor, and both sexes have a mesoscutum with transverse rugae.

Four genera, Epirhyssa Cresson, 1865, Megarhyssa Ashmead, 1900, Rhyssa Gravenhorst, 1829 and Rhyssella Rohwer, 1920, occur in the New World, but only Epirhyssa is species-rich in the Neotropical region. Two genera, Epirhyssa and Megarhyssa, with three species in each genus, were known to occur in Mexico

How to cite this article: Khalaim A.I., Ruíz-Cancino E., Coronado-Blanco J.M. 2021. Darwin wasps (Hymenoptera: Ichneumonidae) of Mexico: subfamily Rhyssinae // Russian Entomol. J. Vol.30. No.3. P.305-313. doi: 10.15298/rusentj.30.3.08 
hitherto [Ruíz-Cancino et al., 2002; Kasparyan, 2002; Khalaim, Ruíz-Cancino, 2013].

Rhyssinae are idiobiont ectoparasitoids of larvae of xylophagous insects, i.e. families Siricidae, Xiphydriidae (Hymenoptera: Symphyta) and Cerambycidae (Coleoptera). Several rhyssine species were introduced into South Africa [Tribe, Cillié, 2004], Australia [Taylor, 1976] and New Zealand [Nuttall, 1974] to control siricid pests in pine forests.

This study aims to review the Mexican species of the subfamily Rhyssinae, provide new faunistic records and give identification keys to genera and species.

\section{Material and Methods}

This work is primarily based on the ichneumonid collection of the Universidad Autónoma de Tamaulipas, Cd. Victoria, Mexico (UAT). Additional material was examined from the following world collections: Townes and Dasch collections (former American Entomological Institute), recently moved to the Utah State University, Logan, Utah, USA (AEIC); California Academy of Sciences, San Francisco, California, USA (CAS); Essig Museum of Entomology, University of California, Berkeley, USA (EMEC); Florida State Collection of Arthropods, Gainesville, Florida, USA (FSCA); Instituto de Biología, Universidad Nacional Autónoma de México, Ciudad de México, Mexico (UNAM); Instituto Nacional de Biodiversidad, Santo Domingo de Heredia, Costa Rica (INBio); and Zoological Institute of the Russian Academy of Sciences, St. Petersburg, Russia (ZISP). Other abbreviations used in this study: ANSP (Academy of Natural Sciences of Philadelphia, Pennsylvania, USA), AMNH (American Museum of Natural History, New York, New York, USA), USNM (National Museum of Natural History, Washington D.C., USA) and LS (Linnean Society, Burlington House, Picadilly, London, UK).

Morphological terminology generally follows that of Gauld [1991]. Photographs were taken with an Olympus OM-D digital camera attached to an Olympus SZX10 stereomicroscope; partially focused images were combined using Helicon Focus 7.6.6 Pro software; all photographs were taken in ZISP. Identification key to the species of Epirhyssa is based on that by Gauld [1991], and the key to the species of Megarhyssa is based on that by Khalaim and Ruíz-Cancino [2013].

\section{Results}

\section{Subfamily Rhyssinae}

Two genera, Epirhyssa with five species and Megarhyssa with three species, are recorded here from Mexico. The genus Rhyssa occurs in the USA and Canada, and one species, $R$. neotropicae Porter, 2002, was described from Honduras [Porter, 2002]. We suppose that Rhyssa can be found in Mexico and therefore this genus is included to the generic key below.

\section{KEY TO GENERA}

1. First tergite free from its sternite, with glymma. Mid leg with apical trochanter unspecialized, without ventral longitudinal ridge. Predominantly Holarctic genus with seven species in the Nearctic region [Townes, Townes, 1960: 396] and one species in Honduras [Porter, 2002: 130]; not recorded from Mexico .................. Rhyssa Gravenhorst

- First tergite fused with its sternite, without glymma (Fig. 20). Mid leg with apical trochanter with a ventral longitudinal ridge (Fig. 21, arrow)

2. Fore wing without areolet (Fig. 6) .. Epirhyssa Cresson — Fore wing with areolet ............... Megarhyssa Ashmead

\section{Genus Epirhyssa Cresson, 1865}

Epirhyssa Cresson, 1865: 39. Type species: Epirhyssa speciosa Cresson, 1865, by subsequent designation [Viereck, 1914: 52].

= Hierax Tosquinet, 1903 .

= Rhyssonota Kriechbaumer, 1890

= Sychnostigma Baltazar, 1961.

REFERENCES. Cresson, 1865: 39 [2 species (both described as new) in Cuba]; Rohwer, 1920: 422 [description; key to 3 species described by Cresson]; Townes, Townes, 1960: 413 [description; 1 species in USA (Arizona)]; 1966: 38 [catalogue; 6 species in Neotropical region; 1 species in Mexico]; Townes, 1969: 141 [description; remarks]; Porter, 1978 [revision of 38 Neotropical species (25 described as new); key]; Carlson, 1979: 355 [catalogue; 1 species in America north of Mexico]; Gauld, 1991: 113 [description; review of 10 species ( 5 described as new) from Costa Rica; key]; Gauld, Wahl, 1997: 448 [addition to key; 2 new species from Costa Rica]; RuízCancino et al., 2002: 646 [checklist; 3 species in Mexico]; Graf, Kumagai, 2004 [1 new species from Brazil]; Gómez et al., 2015 [review of 24 species (10 described as new) from Peruvian Amazonia; key]; Varga, 2020 [1 new species from Kenya].

Epirhyssa is a large tropical genus with about 130 described species. Fifty five species are known in the New World, of them 12 occur in Costa Rica [Gauld, 1991; Gauld, Wahl, 1997]. Only the one widely distributed species, $E$. mexicana Cresson, 1874, is known from the Nearctic region (was recorded from Arizona, USA). Five species of Epirhys$s a$ are found to occur in Mexico.

In China, species of the genus were recorded as parasitoids of wood-boring beetles and sawflies [Sheng, Sun, 2010], but nothing is known about hosts of this genus in the New World. Porter [1978] observed females of Epirhyssa boring into dead trees, especially old and partially rotten trunks, and Gauld [1991] reported E. mexicana probing standing dead trees infested with cerambycid larvae in Costa Rica.

Key to SPECIES OF EPIRHYSSA OCCURRING IN MeXICO

1. Fore wing without blackish spot at distal apex, though sometimes with marginal cell brownish anteriorly (Fig. 16) ........................................... 4. E. theloides Porter

- Fore wing with a distinct, discrete blackish spot at distal apex (Figs 6, 9) ...................................................... 2

2. Flagellum with median band and basal flagellomeres yellow or pale brown, remainder brownish black (Fig. 12). First tergite slender, in female 2.5-3.0 times and in male 3.1-3.6 times as long as posteriorly broad. Female with suranal cornus unusually long, cylindrical (Figs 14-15), with apical flattened area circular.... 3. E. oaxaca Porter

- Flagellum black, sometimes brownish at extreme base and apex, without median pale band (Fig. 1). First tergite in female 1.6-2.3 times and in male 2.5-2.7 times as long as posteriorly broad. Female with suranal cornus short, unspecialized (Figs 7-8), with apical flattened area depressed oval.

3. Occipital carina completely absent. Mesosoma and metaso- 
ma reddish yellow, without black markings; metasomal tergites weakly and narrowly darkened posteriorly ........ 5. E. xoutha Porter

- Occipital carina distinct laterally and ventrally. Mesosoma and metasoma usually with conspicuous brown or black markings
4. Apex of clypeus without median tubercle (Fig. 3). Lateral lobe of mesoscutum yellow, sometimes pale brown centrally (Fig. 5)

2. E. mexicana Cresson

- Apex of clypeus with small median tubercle (as in Fig. 11, arrow). Lateral lobe of mesoscutum with longitudinal black stripe centrally. 1. E. frohbergi Gauld

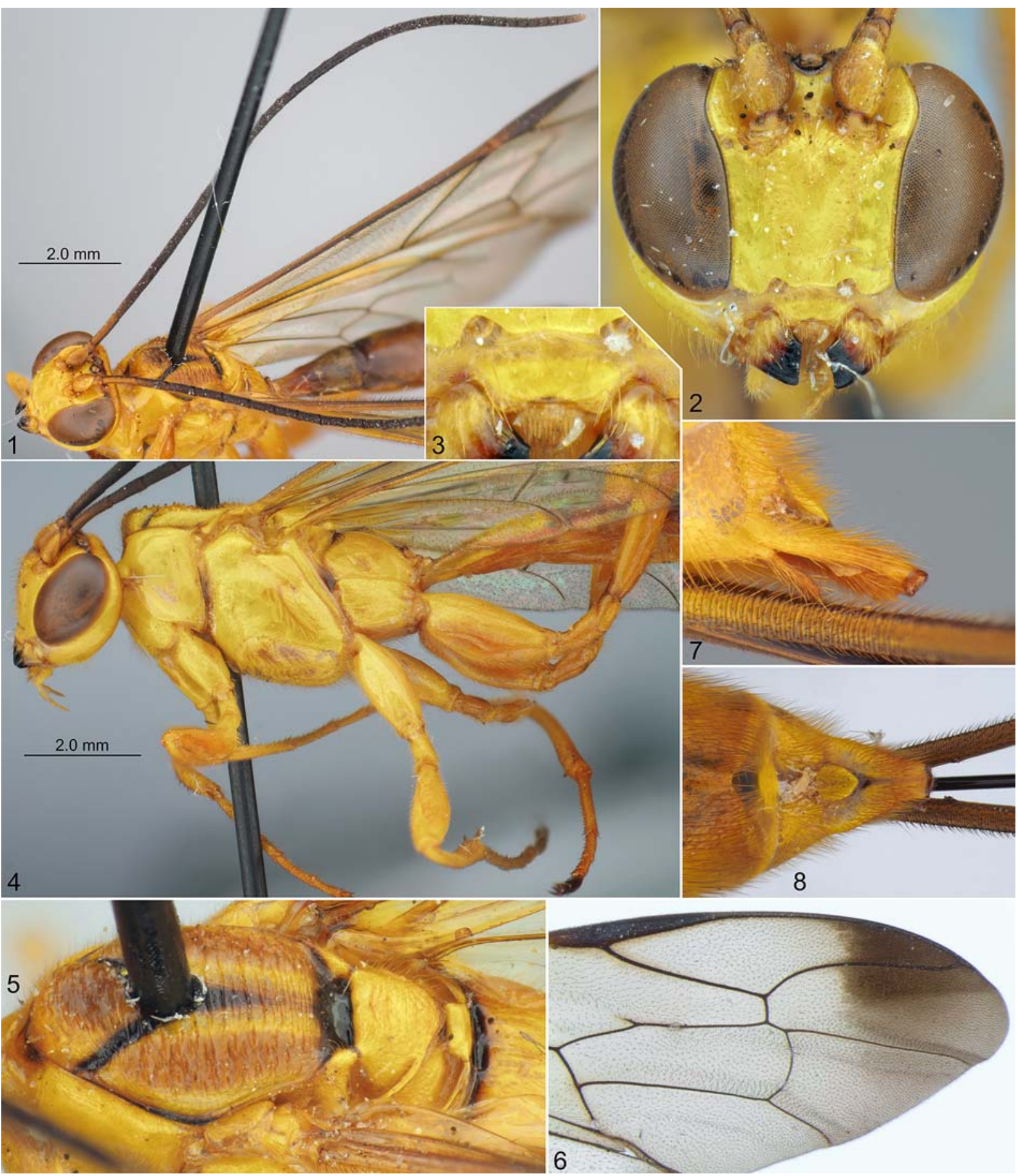

Figs 1-8. Epirhyssa mexicana, female: 1 - head with antennae, dorso-lateral view; 2 - head, front view; 3 - clypeus, front view; 4 head, mesosoma and base of metasoma, lateral view; 5 - mesoscutum and scutellum, dorso-lateral view; 6 - apex of fore wing; 7 - apex of metasoma, lateral view; 8 - apex of metasoma, dorsal view.

Рис. 1-8. Epirhyssa mexicana, самка: 1 - голова с антеннами, сверху и сбоку; 2 - голова, спереди; 3 - клипеус, спереди; 4 голова, мезосома и основание метасомы, сбоку; 5 - мезоскутум и скутеллум, сверху и сбоку; 6 - вершина переднего крыла; 7 вершина метасомы, сбоку; 8 - вершина метасомы, сверху. 


\section{Epirhyssa frohbergi Gauld, 1991}

Epirhyssa frohbergi Gauld, 1991: 124 [holotype female (INBio), Costa Rica, Guanacaste Prov., Guanacaste National Park, Santa Rosa Sector, coastal forest, 10 m, VI.1988, coll. I.D. Gauld].

MATERIAL EXAMINED. Mexico, State of Veracruz:
San Andrés, Biological Station Los Tuxtlas, 210 m, selva alta perennifolia, Malaise trap, 31.III-16.IV.2014, coll. M. Madora, $1 \sigma^{7}$ (UNAM).

DISTRIBUTION. Mexico (Veracruz), Costa Rica. First record from Mexico.

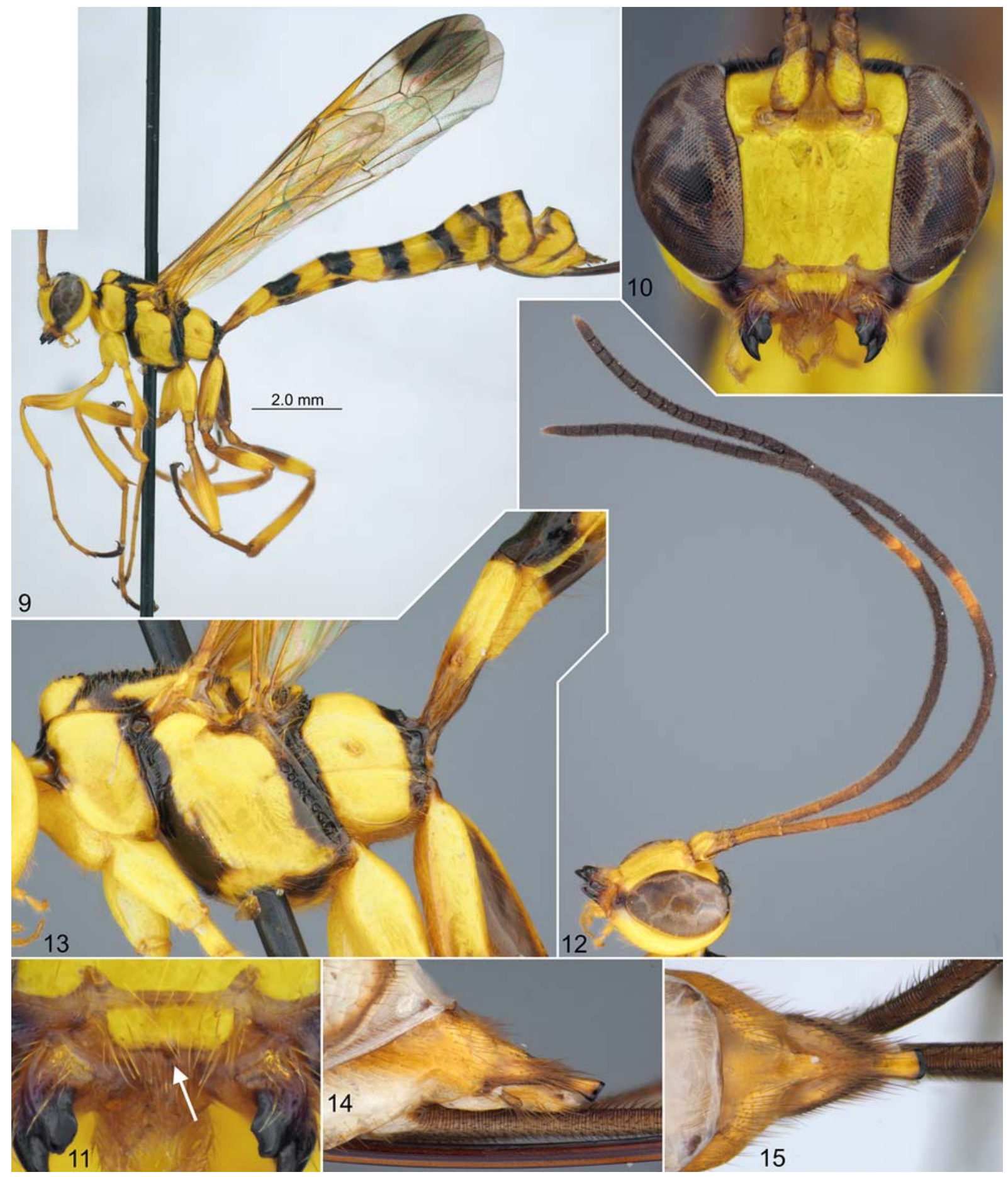

Figs 9-15. Epirhyssa oaxaca, female: 9 - habitus (without antennae and ovipositor), lateral view; 10 - head, front view; 11 - clypeus, front view; 12 - head with antennae, lateral view; 13 - mesosoma and base of metasoma, lateral view; 14 - apex of metasoma, lateral view; 15 - apex of metasoma, dorsal view.

Рис. 9-15. Epirhyssa oaxaca, самка: 9 - габитус (без антенн и яйцеклада), вид сбоку; 10 - голова, вид спереди; 11 - клипеус, вид спереди; 12 - голова с антеннами, вид сбоку; 13 - мезосома и основание метасомы, вид сбоку; 14 — вершина метасомы, вид сбоку; 15 - вершина метасомы, вид сверху. 


\section{Epirhyssa mexicana Cresson, 1874}

Figs $1-8$.

Epirhyssa mexicana Cresson, 1874: 394 [females (ANSP), Mexico, Veracruz, Orizaba, Córdoba].

= Epirhyssa dietrichi Townes in Townes and Townes, 1960 [Gauld, 1991: 119].

= Epirhyssa mexicana var. immaculata Morley, 1913 [Porter, 1978: 393].

REFERENCES. Cameron, 1886: 262 [Mexico (Veracruz), Guatemala)]; Morley, 1913: 4 [E. mexicana var. immaculata; Mexico (Guerrero)], 8 [E. mexicana; Mexico (Guerrero)]; Cresson, 1916: 42 [lectotype female (ANSP) designated; Mexico, Veracruz]; Rohwer,
1920: 422 [key]; Townes, Townes, 1966: 38 [catalogue; Mexico]; Porter, 1978: 390 [E. dietrichi; description; USA (Arizona), Mexico (Morelos), Costa Rica], 392 [description; Epirhyssa mexicana var. immaculata (syn.); Mexico (Nuevo León, Sinaloa, Veracruz, Guerrero, Chiapas), Guatemala]; Carlson, 1979: 356 [E. dietrichi; catalogue]; Ruíz-Cancino, Tejada, 1986: 39 [Mexico (Tamaulipas)]; Maes, 1989: 33 [catalogue; Nicaragua]; Gauld, 1991: 119 [description; Mexico (Veracruz, Guerrero), Guatemala, Costa Rica]; RuízCancino et al., 2002: 646 [checklist; Mexico]; Quicke et al., 2009: 1415 [Belize]; Ruíz-Cancino et al., 2010: 65 [checklist; Mexico (Tamaulipas)].

MATERIAL EXAMINED. Mexico, Tamaulipas: Cd. Victoria, 3-4.VI.1981, coll. E. Ruíz C., 3 of, 1 ○ (UAT). NW of Cd.

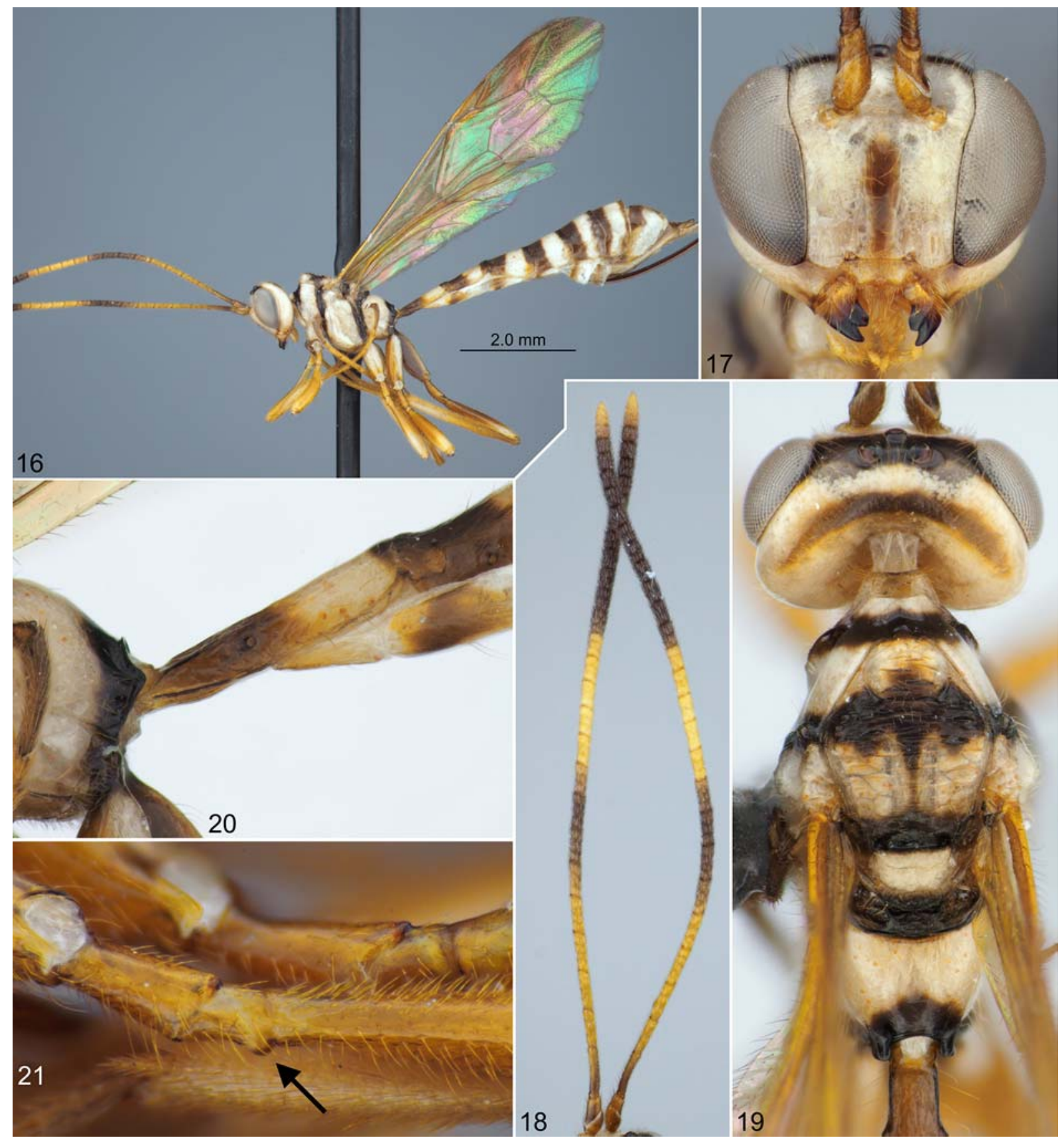

Figs 16-21. Epirhyssa theloides, female: 16 - habitus (without apices of antennae and ovipositor), lateral view; 17 — head, front view; 18 - antennae, dorsal view; 19 - head and mesosoma, dorsal view; 20 - first tergite, lateral view; 21 - trochanters of mid leg, lateral view.

Рис. 16-21. Epirhyssa theloides, самка: 16 - габитус (без вершин антенн и яйцеклада), сбоку; 17 - голова, спереди; $18-$ антенны, сверху; 19 - голова и мезосома, сверху; 20 - первый тергит, сбоку; 21 - вертлуги средней ноги, сбоку. 
Victoria, Los Troncones (park), coll. A.I. Khalaim: 18.III.2008, 2 ㅇ, 1 ○ी (UAT); 25.IV.2009, 1 (ZISP); 13.X.2012, 1 q (ZISP) Same data, but yellow pan trap, 18.III-13.IV.2008, 1 ㅇ (UAT). 15 km SSW of Cd. Victoria, El Madroño, 23.XII.1987, coll. E. Ruíz C., 1 ( (UAT). Cd. Victoria, Cañón del Novillo, 6.X-17.XI.1984, coll. F. Lopez V., 6 우, 10 O $^{\top}$ Or $^{\top}$ (UAT). Same locality, 15.VI.1985, coll. A. del Valle, $1 O^{\top}$ (UAT). Same locality, 5.VIII.1985, coll. H. Serna T., $10^{7}$ (UAT). Gómez Farías, 350 m, 17.IX.2016, col. A.I. Khalaim, 1 q (UAT). Gómez Farías, 16.III.1989, coll. R. Thompson F., 1 ㅇ (UAT). Gómez Farías, Altas Cimas, Malaise trap, 29.V-12.VI.1999, coll. S. Hernández A., 1 + $1 \mathrm{O}^{\top}$ (UAT). Gómez Farías, Los Cedros, Malaise trap, coll. S. Hernández A. (all in UAT): 6-13.III.1999, 1 9 17.IV-1.V.1999, 3 O O $^{7} ; 15-29 . V .1999,2$ o O $^{7}$. San Luís Potosí: El Bonito, $7 \mathrm{mi}$. S of Ciudad Valles, $300 \mathrm{ft} .(=90 \mathrm{~m}), 19$. XII.1970, coll. P.H. \& M. Arnaud, 1 (CAS). Yucatán: Sudzal Chico "SMSP", XI.1999, coll. Hugo Delfin, $2 \mathrm{O}^{7} \mathrm{O}^{7}$ (UAT)

DISTRIBUTION. USA (Arizona), Mexico (Sinaloa, Nuevo León, Tamaulipas, San Luís Potosí, Veracruz, Morelos, Guerrero, Yucatán, Chiapas), Belize, Guatemala, Nicaragua, Costa Rica.

BIOLOGY. In Costa Rica, females of E. mexicana were observed probing standing dead trees infested with cerambycid larvae [Gauld, 1991: 114]. Maes [1989] in his catalogue of Nicaraguan insects mentioned E. mexicana as a parasitoid of coleopterous larvae in wood.

\section{Epirhyssa oaxaca Porter, 1978}

Figs 9-15.

Epirhyssa oaxaca Porter, 1978: 382 [holotype female (AEIC), Mexico, Oaxaca, 6 mi. S. Valle Nacional, 2000 ft. $(=610 \mathrm{~m})$, 18.V.1971, coll. H. Howden].

= Epirhyssa corralesi Gauld, 1991, syn.n.

REFERENCES. Gauld, 1991: 125 [E. corralesi (description); Costa Rica]; Gauld, Wahl, 1997: 451 [E. corralesi; remarks; Costa Rica]; Ruíz-Cancino et al., 2002: 646 [checklist; Mexico]; SánchezGarcía et al., 2015: 828 [checklist; Mexico (Oaxaca)].

MATERIAL EXAMINED. Mexico, Veracruz: San Andrés, Biological Station Los Tuxtlas, $150-250 \mathrm{~m}$, selva alta perennifolia, Malaise trap, coll. M. Madora (all in UNAM): 14.IV-13.V.2013, 1 O’$^{7}$ 16.VIII-17.IX.2013, 1 \%; 31.III-16.IV.2014, 1 9;28.V-16.VI.2014,
1 ㅇ. Same locality and trap, 4-8.X.2014, coll. A.I. Khalaim, 1 우 (ZISP). Oaxaca: 6 mi. S. Valle Nacional, 2000 ft. $(=610 \mathrm{~m}), 18$. V.1971, coll. H. Howden, 1 ( holotype of E. oaxaca; AEIC).

REMARKS. The holotype of E. oaxaca was examined by the senior author and was found to correspond well with the original description of the Costa Rican species E. corralesi, including such important features as long suranal cornus with flattened circular apical area (Figs 14, 15), flagellum with basal and submedian brownish bands (Fig. 12), and clypeus with a distinct median apical tooth (Fig. 11, arrow). Thus, we conclude that $E$. corralesi is a junior synonym of E. oaxaca, syn.n.

VARIATION. Examined specimens from Veracruz are conspicuously smaller than the holotype of E. oaxaca. Some Mexican specimens are rather pale with legs and first tergite only with pale brown markings and hind coxa predominantly yellow with brown marks on ventral and inner sides. Occipital carina is completely absent ventrally, or vestigial and more or less reaching the hypostomal carina in Mexican material, and complete ventrally and joining to the hypostomal carina in Costa Rican specimens, according to the description of E. corralesi by Gauld [1991].

DISTRIBUTION. Mexico (Veracruz, Oaxaca), Costa Rica.

\section{Epirhyssa theloides Porter, 1978}

Figs 16-24.

Epirhyssa theloides Porter, 1978: 370 [holotype female (FSCA), Costa Rica, Instituto Interamericano de Ciencias Agrícolas ca. Turrialba, VIII.1963, coll. C. Porter].

REFERENCES. Gauld, 1991: 131 [description; Costa Rica].

MATERIAL EXAMINED. Mexico, Veracruz: San Andrés, Biological Station Los Tuxtlas, 150-210 m, selva alta perennifolia, Malaise trap, coll. M. Madora: 10.III-14.IV.2013, 1 q (UNAM); 13.V-16.VI.2013, 1 q (UNAM); 30.XI-17.XII.2013, 1 \% (ZISP); 16-31.III.2014, 1 ㅇ (UNAM); 14.VII-1.VIII.2014, 1 ㅇ (ZISP). Guatemala: Guatemala Department, Fraijanes, Finca San Antonio, 1800 m, VI.1987, coll. Mauger, 2 우 (AEIC). Costa Rica: Heredia Prov., Braulio Carrillo National Park, $9 \mathrm{~km}$ E of El Tunel, 1000 m, IX.1990, coll. I.D. Gauld, 1 + (det. I.D. Gauld; UAT).

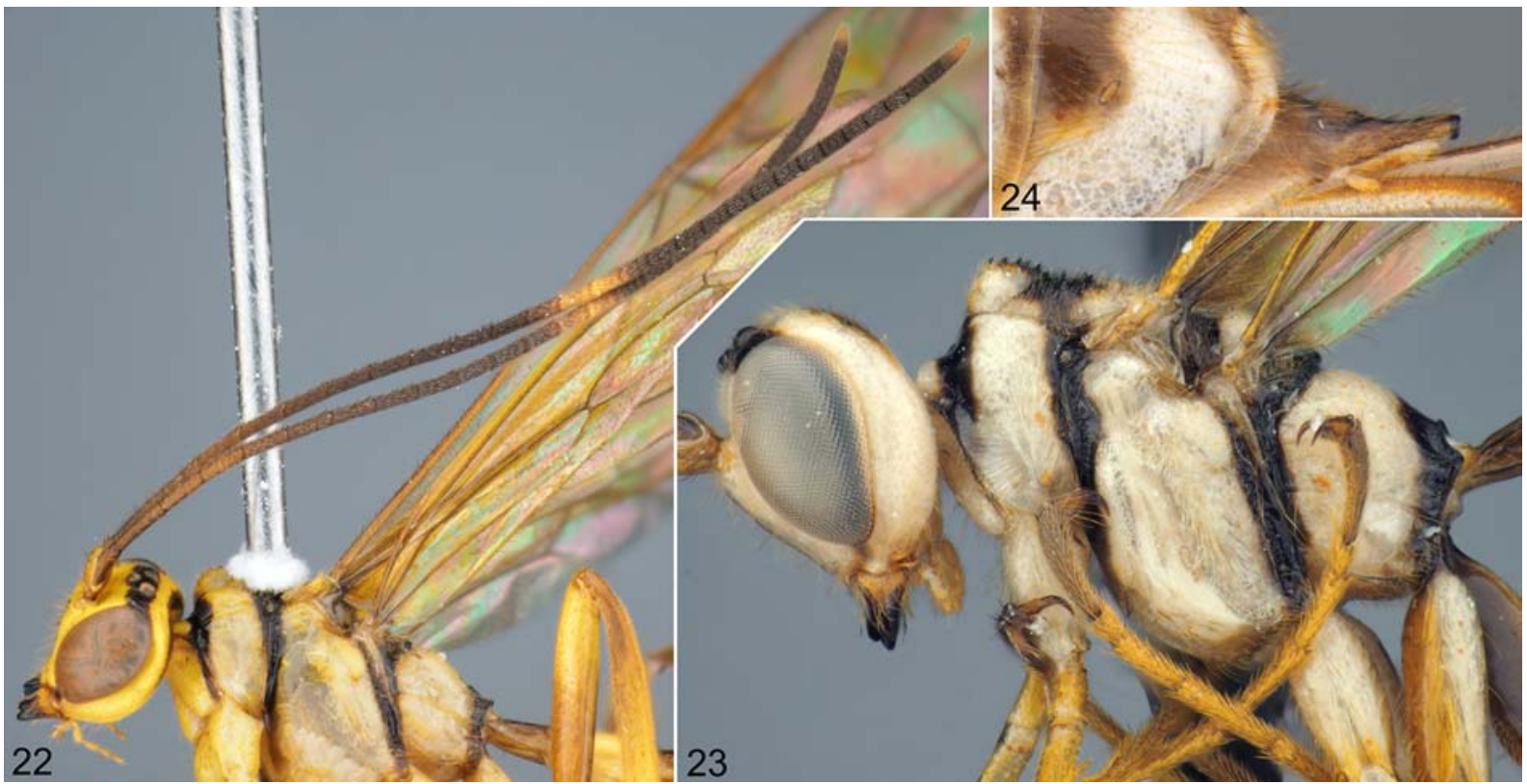

Figs 22-24. Epirhyssa theloides, female: 22 - head with antennae, lateral view; 23 -head and mesosoma, lateral view; 24 - apex of metasoma, lateral view.

Pис. 22-24. Epirhyssa theloides, самка: 22 - голова с антеннами, сбоку; 23 - голова и мезосома, вид сбоку; 24 - вершина метасомы, сбоку. 
VARIATION. Pale bands on antennal flagellum vary from bright and distinct (Fig. 18) to rather weak and inconspicuous (Fig. 22).

DISTRIBUTION. Mexico (Veracruz), Guatemala, Costa Rica. First records from Mexico and Guatemala.

\section{Epirhyssa xoutha Porter, 1978}

Epirhyssa xoutha Porter, 1978: 372 [holotype female (AMNH), Trinidad, Arima Valley, 31.I.1957; "Mexico"].

REFERENCES. Ruíz-Cancino et al., 2002: 646 [checklist; Mexico].

DISTRIBUTION. Mexico (no further details), Trinidad and Tobago.

\section{Genus Megarhyssa Ashmead, 1900}

Megarhyssa Ashmead, 1900: 368 (new name for Thalessa Holmgren, 1859). Type species: Ichneumon clauatus Fabricius, 1798.

= Eurhyssa Derksen, 1941. 1853)

= Thalessa Holmgren, 1859 (name preoccupied by Adams,

REFERENCES. Rohwer, 1920: 425 [description; review of 4 Nearctic species; key]. Townes, Townes, 1960: 415 [description; review of 4 Nearctic species; key]. Townes, Townes, 1966: 38 [catalogue; 1 species in Neotropical region; 1 species in Mexico]. Townes, 1969: 139 [description remarks]. Carlson, 1979: 353 [catalogue; 4 species in America north of Mexico]. Ruíz-Cancino et al., 2002: 646 [checklist; 1 species in Mexico]. Kasparyan, 2002 [1 new species from Mexico (Mexico)]. Khalaim, Ruíz-Cancino, 2013 [review of 3 species from Mexico (1 described as new); key]. Pook et al., 2016 [key to 4 Nearctic species].

The genus Megarhyssa comprises 37 species occurring predominantly in the Holarctic and Oriental regions, with most species in tropical Asia [Kasparyan, 2002]. Four species occur in the USA and Canada, and one of them, $M$. macrurus (Linnaeus, 1771), is also known from northern Mexico. Two more species, M. verae Kasparyan, 2002 and M. gratiosa Khalaim et Ruíz-Cancino, 2013, were recently described from central and southern Mexico [Kasparyan, 2002; Khalaim, Ruíz-Cancino, 2013]. In Mexico, the genus is very rarely collected, but in the USA and Canada it seems to be more abundant in forests.

Species of Megarhyssa are idiobiont ectoparasitoids of xylophagous sawflies of the family Siricidae (Hymenoptera) on deciduous and sometimes on coniferous trees.

\section{Key to species of Megarhyssa occurring in Mexico}

1. Metasoma laterally yellow, with broad dorsal longitudinal black stripe extending along entire length of metasoma. Fore wing hyaline with conspicuous subapical dark mark at apex of radial cell. Flagellum of antenna blackish with broad subapical pale band. Ovipositor sheath 3.4 times as long as fore wing ......

.................. 1. M. gratiosa Khalaim et Ruíz-Cancino

- Metasoma with variable amount of yellow, reddish orange and black; tergites often transversely banded or with dorsal and/or lateral marks, but never with continuous median black stripe extending along entire length of metasoma. Fore wing without apical dark mark, or with radial cell darkened only at base. Flagellum of antenna more or less entirely black, sometimes somewhat lighter in the apical half, never with contrasting pale band. Ovipositor sheath about 1.9-3.0 times as long as fore wing .......

2. Hind leg with coxa and tarsus entirely black, femur and tibia black in basal 0.8 and yellow in apical 0.2. Head and mesosoma black with yellow markings. Metasoma extensively black, tergites 1 and 2 with pre-apical dorsomedian yellow marks, tergite 3 and following tergites with lateral yellow markings. Malar space 1.4 times as long as apical mandibular width. Ovipositor sheath almost twice as long as fore wing ............................. 3. M. verae Kasparyan

- Hind leg predominantly brownish orange with yellow marks. Head and mesosoma predominantly yellow and brown. Metasoma yellow to reddish brown, with more or less distinct transverse pre-apical yellow bands on tergites. Malar space 0.7 times as long as apical mandibular width. Ovipositor sheath 3.0 times as long as fore wing 2. M. macrurus macrurus (Linnaeus)

\section{Megarhyssa gratiosa Khalaim et Ruíz-Cancino,} 2013

Megarhyssa gratiosa Khalaim and Ruíz-Cancino, 2013: 197 [holotype female (EMEC), Mexico, Chiapas, $27 \mathrm{mi} .(=43.5 \mathrm{~km}) \mathrm{N}$ of Ocozocoautla [de Espinosa], 21.VII.1965, coll. D.R. Pauson].

REFERENCES. Ibarra-Garibay et al., 2015 [Mexico (Campeche)].

COMPARISON. This species may easily be recognized by the remarkable colour pattern of the metasoma which is yellow with broad dorsal black stripe extending along its entire length. Megarhyssa gratiosa also differs from the other two Mexican species by having a hyaline fore wing with a conspicuous dark spot at apex of the radial cell and the longer ovipositor, and from $M$. verae in having flagellum with 56 flagellomeres (vs 36 flagellomeres in M. verae) and a shorter malar space.

DISTRIBUTION. Mexico (Campeche, Chiapas).

\section{Megarhyssa macrurus (Linnaeus, 1771)}

Ichneumon macrurus Linnaeus, 1771: 540 [lectotype female (LS), USA, South Carolina, near Charleston].

=Ichneumon georgicus Megerle, 1802 [Townes, Townes, 1960].

= Megarhyssa lunator phaeoptila Michener, 1939 [Townes, Townes, 1960].

$=$ Thalessa ? histrio Kriechbaumer, 1890 (name preoccupied by Ichneumon histrio Christ, 1791).

REFERENCES. Rohwer, 1920: 428 [Thalessa? histrio; remarks]; Townes, Townes, 1960: 429 [description; review, key to 3 subspecies; biology], 434 [Ichneumon georgicus (syn.), M. lunator phaeoptila (syn.)]; Townes, 1961: 108 [notes on type]; Stillwell, 1967: 688 [host; Canada (New Brunswick)]; Fitton, 1978: 369 [lectotype female (LS) designated; USA, South Carolina, near Charleston]; Carlson, 1979: 354 [catalogue; 2 subspecies in America north of Mexico]; Ruíz-Cancino et al., 2002: 646 [checklist; Mexico]; Pook et al., 2016: 143 [diagnosis, photographs].

There are three Nearctic subspecies that differ from each other mostly by their colour pattern [Townes, Townes, 1960; Pook et al., 2016]. One subspecies occurs in the northern parts of Mexico.

BIOLOGY. Parasitoid of horntail sawfly Tremex columba (L.) (Hymenoptera: Siricidae) [Townes, Townes, 1960; Stillwell, 1967].

DISTRIBUTION. Canada, USA, Mexico (Chihuahua, Nuevo León).

\section{Megarhyssa macrurus macrurus s.str.}

REFERENCES. Townes, Townes, 1960: 434 [description; Mexico (Chihuahua)]. 1966: 38 [catalogue; Mexico]. Carlson, 1979: 354 [catalogue].

MATERIAL EXAMINED. Mexico, Nuevo León: Monterrey, La Estanzuela, II.1986, coll. L.O. Tejada, 1 +, 1 O$^{7}$ (UAT). USA, Texas: Mason Country, 2 mi. E of Fredonia, 14.IV.1991, coll. K. King, 1 ㅇ (UAT).

DISTRIBUTION. USA (from Texas to Georgia and Florida), Mexico (Chihuahua, Nuevo León). 


\section{Megarhyssa verae Kasparyan, 2002}

Megarhyssa verae Kasparyan, 2002: 305 [holotype female (USNM), Mexico, State of Mexico, $6 \mathrm{~km} \mathrm{~W}$ of lake Zempoala, 2.X.1991, coll. A.L. Norrbom].

COMPARISON. Megarhyssa verae resembles the Nearctic M. nortoni (Cresson, 1864) in colour pattern of wings and metasoma, but differs from this and other Nearctic species of Megarhyssa by hind femur and tibia entirely black dorsally, and by unusual combination of yellow markings on the mesopleuron. der).

DISTRIBUTION. Mexico (State of Mexico/Morelos bor-

Acknowledgements. This work was supported by the PRODEP project "Taxonomical and biological studies of pests and natural enemies in Mexico". The work of the senior author was also supported by the Russian Foundation for Basic Research (project no. 19-04-00027) and performed in the framework of the Russian State Research Project no. ÀÀÀÀ-À19-119020690101-6.

Competing interests. The authors declare no competing interests.

\section{References}

Ashmead W.H. 1900. Some changes in generic names in Hymenoptera // The Canadian Entomologist. Vol.32. No.12. P.368. https://doi.org/10.4039/Ent32368a-12.

Broad G.R., Shaw M.R., Fitton M.G. 2018. Ichneumonid wasps (Hymenoptera: Ichneumonidae): their classification and biology // Handbooks for the Identification of British Insects. Vol.7. Pt.12. 418 pp.

Cameron P. 1886. Hymenoptera // Godman F.D., Salvin O. (eds.) Biologia Centrali-Americana; or, Contributions to the knowledge of the fauna and flora of Mexico and Central America. Zoology. Vol.1. P.241-328.

Carlson R.W. 1979. Family Ichneumonidae // Krombein K.V., Hurd Jr.P.D., Smith D.R., Burks B.D. (eds.). Catalog of Hymenoptera in America north of Mexico. Smithsonian Institution Press, Washington. P.315-740.

Cresson E.T. 1865. On the Hymenoptera of Cuba // Proceedings of the Entomological Society of Philadelphia. Vol.4. P.1-200.

Cresson E.T. 1874. Descriptions of Mexican Ichneumonidae // Proceedings of the Academy of Natural Sciences of Philadelphia. Vol.1873. Pt.III. P.374-413.

Cresson E.T. 1916. The Cresson types of Hymenoptera // Memoirs of the American Entomological Society. Vol.1. P.1-141.

Fitton M.G. 1978. The species of "Ichneumon" (Hymenoptera) described by Linnaeus // Biological Journal of the Linnean Society. Vol.10. P.361-383.

Fitton M.G., Gauld I.D. 1976. The family-group names of the Ichneumonidae (excluding Ichneumoninae) (Hymenoptera) // Systematic Entomology. Vol.1. P.247-258.

Gauld I.D. 1991. The Ichneumonidae of Costa Rica, 1. Introduction, keys to subfamilies, and keys to the species of the lower Pimpliform subfamilies Rhyssinae, Poemeniinae, Acaenitinae and Cylloceriinae // Memoirs of the American Entomological Institute. Vol.47. P.1-589.

Gauld I.D., Wahl D. 1997. The Ichneumonidae of Costa Rica, 2. Introduction and keys to species of the smaller subfamilies Anomaloninae, Ctenopelmatinae, Diplazontinae, Lycorininae, Phrudinae, Tryphoninae (excluding Netelia) and Xoridinae, with an appendix on the Rhyssinae with a cladistic analysis of the genera and subgenera of Xoridinae // Memoirs of the American Entomological Institute. Vol.57. P.1-485.

Gómez I.C., Sääksjärvi I.E., Puhakka L., Castillo C., Bordera S. 2015. The Peruvian Amazonian species of Epirhyssa Cresson (Hymenoptera: Ichneumonidae: Rhyssinae), with notes on trop- ical species richness // Zootaxa. Vol.3937. No.2. P.311-336. https://doi.org/10.11646/zootaxa.3937.2.4.

Graf V., Kumagai A.F. 2004. Uma espécie nova de Epirhyssa Cresson (Ichneumonidae, Hymenoptera) do Brasil // Acta Biológica Paranaense. Vol.33. No.1-4. P.21-25.

Ibarra-Garibay L.E., Ruíz-Cancino E., Coronado-Blanco J.M. 2015. Nuevo registro de Megarhyssa gratiosa Khalaim \& Ruíz-Cancino (Hymenoptera: Ichneumonidae: Rhyssinae) en al Estado de Campeche, México // Folia Entomológica Mexicana (nueva serie). Vol.1. No.2. P.76-78.

Kamath M.K., Gupta V.K. 1972. Ichneumonologia Orientalis or a monographic study of Oriental Ichneumonidae. Part II. The tribe Rhyssini (Hymenoptera: Ichneumonidae) // Oriental Insects Monograph. Vol.2. P.1-300.

Kasparyan D.R. 2002. A new species of Megarhyssa Ashmead, 1900 (Hymenoptera: Ichneumonidae) from Mexico // Russian Entomological Journal. Vol.11. No.3. P.305-306.

Khalaim A.I., Ruíz-Cancino E. 2013. A new species of Megarhyssa Ashmead (Hymenoptera: Ichneumonidae: Rhyssinae) from tropical Mexico with a key to Mexican species // Zootaxa. Vol.3619. No.2. P.195-200. https://doi.org/10.11646/zootaxa.3619.2.7.

Klopfstein S., Bernardo F.S., Shaw M.R., Alvarado M., Bennett A.M.R., Dal Pos D., Giannotta M., Herrera Florez A.F., Karlsson D., Khalaim A.I., Lima A.R., Mikó I., Sääksjärvi I.E., Shimizu S., Spasojevic T., van Noort S., Vilhelmsen L., Broad G.R. 2019. Darwin wasps: a new name heralds renewed efforts to unravel the evolutionary history of Ichneumonidae // Entomological Communications. Vol.1. ec01006. https://doi.org/10.37486/2675-1305.ec01006.

Linnaeus C. von. 1771. Mantissa Plantarum altera // Holmiae. P.143-588.

Maes J.-M. 1989. Catálogo de los insectos controladores biológicos en Nicaragua. Volumen III. Insectos parasitoides // Revista Nicaraguense de Entomología. Vol.10. P.1-138.

Morley C. 1913. A revision of the Ichneumonidae based on the collection in the British Museum (Natural History) with descriptions of new genera and species. Part II. Tribes Rhyssides, Echthromorphides, Anomalides and Paniscides. London, British Museum. 140 pp.

Nuttall M.J. 1974. Rhyssa lineolata (Hymenoptera: Ichneumonidae), as a parasite of Sirex noctilio in New Zealand // New Zealand Journal of Forestry Science. Vol.4. No.3. P.487-494.

Pook V.G., Sharkey M.J., Wahl D.B. 2016. Key to the species of Megarhyssa (Hymenoptera, Ichneumonidae, Rhyssinae) in America, north of Mexico // Deutsche Entomologische Zeitschrift. Vol.63. No.1. P.137-148. https://doi.org/10.3897/ dez.63.7619.

Porter C.C. 1978. A revision of the genus Epirhyssa (Hymenoptera, Ichneumonidae) // Studia Entomologica. Vol.20. No.1-4. P.297-412.

Porter C.C. 2002. New species and records of Rhyssa and Rhyssella (Hymenoptera: Ichneumonidae: Rhyssinae) from Florida and Central America // Insecta Mundi. Vol.15. No.3(2001). P.129-137.

Quicke D.L.J., Laurenne N.M., Fitton M.G., Broad G.R. 2009. A thousand and one wasps: a $28 \mathrm{~S}$ rDNA and morphological phylogeny of the Ichneumonidae (Insecta: Hymenoptera) with an investigation into alignment parameter space and elision // Journal of Natural History. Vol.43. No.23-24. P.1305-1421. https://doi.org/10.1080/00222930902807783.

Rohwer S.A. 1920. The North American Ichneumon-flies of the tribes Labenini, Rhyssini, Xoridini, Odontomerini, and Phytodietini // Proceedings of the United States National Museum. Vol.57. No.2317. P.405-474. https://doi.org/10.5479/ si.00963801.57-2317.405.

Ruíz-Cancino E., Tejada L.O. 1986. Géneros de Ichneumonidae del Noreste de Mexico // The Southwestern Entomologist. Vol.11. No.1. P.37-41.

Ruíz-Cancino E., Kasparyan D.R., Coronado-Blanco J.M. 2002. 37. Ichneumonidae // Llorente-Bousquets J., Morrone J.J. (eds.). Biodiversidad, Taxonomía y Biogeografía de Artrópodos de México: Hacia una síntesis de su conocimiento. Conabio-Ecosur-Bayer, México. P.631-646.

Ruíz-Cancino E., Kasparyan D.R., Coronado-Blanco J.M., Myartseva S.N., Trjapitzin V.A., Hernández-Aguilar S.G., García-Jiménez J. 2010. Himenópteros de la Reserva "El Cielo", Tamaulipas, 
México // Dugesiana. Vol.17. No.1. P.53-71.

Sánchez-García J.A., Jarquín-López R., Martínez-Martínez L., Coronado-Blanco J.M., Ruíz-Cancino E. 2015. Ichneumonoidea (Hymenoptera) del Estado de Oaxaca, México // Entomología Mexicana. Vol.2. P.823-829.

Sheng M.-L., Sun S.-P. 2010. Parasitic ichneumonids on woodborers in China (Hymenoptera: Ichneumonidae). Science Press, Beijing, China. 338 pp. [In Chinese]

Stillwell M.A. 1967. The pigeon tremex, Tremex columba (Hymenoptera: Siricidea), in New Brunswick // The Canadian Entomologist. Vol.99. No.7.P.685-689. https://doi.org/10.4039/ Ent99685-7.

Taylor K.L. 1976. The introduction and establishment of insect parasitoids to control Sirex noctilio in Australia // Entomophaga. Vol.21. No.4. P.429-440. https://doi.org/10.1007/BF02371642.

Townes H.K. 1961. Annotated list of the types of Nearctic ichneumonids in European museums (Hymenoptera) // Proceedings of the Entomological Society of Washington. Vol.63. P.103-113.

Townes H.K. 1969. The genera of Ichneumonidae, Part 1 // Memoirs of the American Entomological Institute. Vol.11. P.1-300.

Townes H.K., Townes M. 1960. Ichneumon-flies of America North of Mexico: 2. Subfamilies Ephialtinae, Xoridinae, Acaenitinae //
United States National Museum Bulletin. Vol.216. No.2. P.1676.

Townes H.K., Townes M. 1966. A catalogue and reclassification of the Neotropic Ichneumonidae // Memoirs of the American Entomological Institute. Vol.8. P.1-367.

Tribe G.D., Cillié J.J. 2004. The spread of Sirex noctilio Fabricius (Hymenoptera: Siricidae) in South African pine plantations and the introduction and establishment of its biological control agents // African Entomology. Vol.12. No.1. P.9-17.

Varga O. 2020. First record of Epirhyssa Cresson, 1865 (Hymenoptera, Ichneumonidae, Rhyssinae) from Kenya // Zootaxa. Vol.4852. No.5. P.590-593. https://doi.org/10.11646/zootaxa.4852.5.9.

Viereck H.L. 1914. Type species of the genera of Ichneumon flies // United States National Museum Bulletin. Vol.83. P.1-186.

Wahl D.B., Gauld I.D. 1998. The cladistics and higher classifcation of the Pimpliformes (Hymenoptera: Ichneumonidae) // Systematic Entomology. Vol.23. No.3. P.265-298. https://doi.org/ 10.1046/j.1365-3113.1998.00057.x.

Yu D.S.K., Achterberg C. van, Horstmann K. 2016. Taxapad 2016 , Ichneumonoidea 2015. Database on flash-drive. Nepean, Ontario, Canada. 